\title{
Role of Governance in Debt-Growth Relationship: Evidence from Panel Data Estimations
}

\author{
Qamar Abbas ${ }^{1} \mathbb{D}$, Li Junqing ${ }^{1, *}$, Muhammad Ramzan ${ }^{1}$ and Sumbal Fatima ${ }^{2}$ \\ 1 School of Economics, Nankai University, Tianjin 300071, China; abbasqamar86@gmail.com (Q.A.); \\ ramzanalambwp@gmail.com (M.R.) \\ 2 Higher Education Research Institute, Zhou Enlai School of Government, Nankai University, \\ Tianjin 300071, China; fatima.aiou@hotmail.com \\ * Correspondence: leejqdoc@163.com
}

Citation: Abbas, Q.; Junqing, L.; Ramzan, M.; Fatima, S. Role of Governance in Debt-Growth Relationship: Evidence from Panel Data Estimations. Sustainability 2021, 13, 5954. https://doi.org/10.3390/ su13115954

Academic Editors: Bruce Morley and Antonio M. López Hernandez

Received: 20 April 2021

Accepted: 20 May 2021

Published: 25 May 2021

Publisher's Note: MDPI stays neutral with regard to jurisdictional claims in published maps and institutional affiliations.

Copyright: (c) 2021 by the authors. Licensee MDPI, Basel, Switzerland. This article is an open access article distributed under the terms and conditions of the Creative Commons Attribution (CC BY) license (https:/ / creativecommons.org/licenses/by/ $4.0 /)$.

\begin{abstract}
This paper provides an empirical analysis of the relationship between debt and national output mediated by a measure of the quality of state governance. Using WGIs dataset of 106 countries for the period 1996-2015, the paper analyzes the mediated effect of governance on debt-growth relationship. For this purpose, we use the fixed effect (LSDV) and system GMM estimation technique in order to overcome the possible problem of endogeneity. Results show the non-linear pattern between public debt and economic growth via governance. Although, public debt has negative impact on economic growth, but the results are statistically positive and significant when public debt is interacted with governance, which confirms that governance is a channel by which public debt influences economic growth. Moreover, we calculate the threshold of governance which shows that the public debt has positive impact on economic growth when the governance level is higher than the threshold and adversely affects the economic growth in the case of low level of governance than threshold. Evidence from this study reveals the fact that governance plays a mediating role in debtgrowth relationship as there is a pattern of complementarity between public debt and governance: the higher the level of governance, the lesser the adverse effect of public debt on economic growth.
\end{abstract}

Keywords: public debt; governance; economic growth; system GMM estimator

\section{Introduction}

The recent economic crisis has produced a sharp rise in public debt levels across the globe. The rise in public debt levels greatly influenced the determinants of economic growth and demanded many researchers and governments to seek out this phenomenon [1]. According to a report of IMF (2016), the impact of public debt on economic growth is widespread worldwide and even in some advanced countries, debt-growth ratio has surpassed 50 percent while in some countries such as Japan, Greece and Italy, this ratio is more than 100 percent. Many countries, particularly developing and underdeveloped countries, face a fiscal deficit and fragile growth due to continued growth in debt level.

Most studies show a non-linear negative impact of public debt on economic growth, which conforms to neo-classical and endogenous growth models [2,3]. Several previous studies report that higher level of debt affects not only capital accumulation, but GDP growth as well through increased interest rates and higher future taxes [4,5], high inflation ratio and an increased degree of ambiguity in future policies. Over the years, the level of public debt has become an ongoing political debate not only for developing countries but also for emerging economies. Public debt has been demonstrated to have an adverse effect on growth and this negative impact sometimes becomes so significant that GDP growth becomes negative. Moreover, the authors propose a minimum threshold for the level of debt and suggest that countries remain below this value. High government debt limits the possibilities of counter-cyclical fiscal policies and therefore higher volatility as well as reducing future growth. As a result, public debt undermines macroeconomic stability. 
Continuous growth has been a key objective of all governments and to achieve sustainable growth, governments must control the level of public debt. Consequently, researchers are interested in examining the debt levels and its effects on different economies. As described by [6], the key objective for governments is to achieve sustainable growth and researchers consider that public debt is the necessary condition for sustainable growth. Countries face the problem of attaining and maintaining sustainable debt levels compatible with sustainable growth. In terms of sustainability, it may be argued that growth based on shortterm public debt, rather than long-term productivity, is unsustainable. Hence, worries about the build-up of sovereign debt and countries face debt overhang. Moreover, debt overhang continues to be a major threat to many advanced and developing economies [7]. Additionally, some studies illustrate that, in developing countries, debt-growth ratio does not depend solely on debt size. Furthermore, institutional quality and policies play a major role in the relationship of these two. Against this background, few studies, such as [8-10], demonstrate that quality of policies and institutions are required to foster investment, sustainable growth and get rid of high debt.

In 1989, the World Bank used the term 'good governance'. Since then, it has been used and applied in numerous fields of study. Over the past few years, the quality of governance has played a critical role in economic growth. This phenomenon has been supported by many international organizations such as the World Bank, the United Nations, the Organization for Economic Cooperation and Development, the International Monetary Fund and the Asia-Pacific Economic Cooperation Conference. Good governance is considered to be an essential condition for promoting the country's competitiveness and improving individuals' life quality. Good governance encourages investment by protecting property rights, accountability controls the corruption, and effective regulation sustains competition [11]. There is, therefore, a consensus that good governance makes it possible to manage the debt efficiently and effectively by adopting sound fiscal and monetary policies. As such, good governance is a key tool for economic development. Governance has become a major field of research for measuring its impact on economic growth in recent times [12].

Traditional economic research concentrates solely on the factors linked to economic growth and debt, however, after exploring the non-economic factors and their role in economic growth, attention begins to increase. Non-economic factors such as institutional quality play a significant role in debt accumulation [13]. Some recent studies demonstrate that public debt is a function of corruption [6]; taking this into account, authors of [14] study the relationship between governance and public debt, and outcomes demonstrated the reason behind high debt ratio is poor governance. To sum up, poor governance has serious implications for economic growth and rationale for higher public debt ratios.

In this paper, our main objective is to study debt-growth with an emphasis on the role of governance. Our main contribution has been to analyze the intermediation effect of governance and calculate its threshold value of economic growth and debt relationship. This study is useful for policymakers to understand the intermediation effect of governance and its utility in the choice of debt to growth ratio, enhancing growth ratio and economic stability.

For this purpose, we estimate the balanced data from the panel of 106 countries covering the period 1996-2015. We start our estimation using fixed effects (least square dummy variable) estimation methodology and then we employ system GMM (generalized method of moments) estimation technique. The system GMM method is widely used to address a possible endogeneity problem such as inverse causality, omitted variables bias and simultaneity biasedness problem. The results of our estimates confirm the negative impact of public debt on economic growth. Moreover, the intensity of this negative effect is lower when countries have higher level of good governance and vice versa in case of poor governance. To be more precise, the higher the level of governance, the less the public debt will adversely affect economic growth. Additionally, we find the threshold level of governance above which public debt tends to positively impact on economic 
growth. Countries that have poor governance or a low level of governance must improve governance quality to deal with the negative effects of public debt.

The main limitation in our research is that governance and public debt are jointly endogenous with economic growth. This may cause biases in our estimation resulting from simultaneity or reverse causality. To deal with this problem, previous literature has pointed out several remedies and there is still debate about which technique is the most appropriate. In our paper, we used annual data as well as 3 years of averaged data of the sampled countries.

The paper presentation is as follows: the theoretical basis is described in Section 2. Section 3 provides model, estimation approach and the data. Results and key findings are outlined in Section 4. The final section concludes the research and discusses a number of policy implications.

\section{Theoretical Basis}

\subsection{Public Debt and Economic Growth}

Public debt has a destructive effect on economic growth suggested by the classical economists like Smith [15], Mill [16] and Ricardo [17]. The Ricardian equivalence explains that the consumption of an individual or a family is based on the lifetime present value of their after-tax income. Moreover, this theory indicates that the public spending, whether financed by taxation or borrowing, is equal. Under this scenario, the government's decision to reduce taxes to boost the economy means that individuals save more by buying the bonds. Thus, as Ricardo pointed out, government indebtedness has a neutral impact on economic growth. Although, Keynesian macroeconomic model of investment savingliquidity preference and money supply (IS-LM) describes that if the increase in public debt prompted by deficit-financed, fiscal policy increases the level of income, and the transaction demands for money and prices, then this causes higher interest rate on public bonds due to a fixed money supply. In accordance with Keynesian theory, if the private sector considers public bonds to be a net asset, the deficit will further exacerbate private spending, transaction demand, interest rates, and prices. The effects of expansionary fiscal policy on capital formation can be reinforced by accelerated effects and thus boost economic growth. On the other hand, monetarists argued that the macroeconomic effect of the financed debt drives out private investment by raising interest rates. As a result, public debt will therefore have an adverse effect on economic growth. Moreover, the theory of debt overhang suggests that if future debt increased beyond the country's repayment capacity, the projected debt servicing costs will discourage domestic and foreign investment, and thereby hinder economic growth [18].

The conventional view on the debt-growth relationship indicates that, in the short term, public debt exerts a positive influence on growth by driving aggregate demand [19]. However, some previous studies have pointed to a negative debt-growth relationship and contradict the Ricardian equilibrium [20-22], However, a few studies support the Barro idea of Ricardian equivalency [23,24]. Additionally, there are some studies with mixed results [25]. Nonetheless, this issue has yet to be resolved, but beyond this conventional view, in recent times, researchers mostly examined the debt-growth relationship through various channels.

Some studies suggest that high public debt is very harmful in the long run. A country with higher indebtedness level not only has to pay long-term interest but also faces the sovereign risk [26-29]. Other studies examine the channel of tax increases distorted by high government debt [4,5]. Higher indebtedness leads to inflation [30-32]. However, authors of [33] follow the path of declining public spending on infrastructure. High levels of debt can limit discretionary counter-cyclical policies, consequently leading to greater volatility in the economy, thus reduction in growth [34]. High indebtedness has an extreme case when it affects the banking sector and creates monetary crisis, which leads to economic instability [35]. 


\subsection{Governance and Economic Growth}

Governance is comprised of traditions and institutes through which authority of a state is exerted. Governance includes how governments are selected, monitored and replaced; the governments' capacity to effectively develop and implement sound policies, and respect for citizens and the state with regard to the institutions that govern economic and social interaction between citizens and state. Since the late 1990s, governance has been an important part of international organizations. The WGIs is a widely used tool to measure the governance. It is comprised of six dimensions of governance as given in the World Bank WGIs database. Based on the definition of governance provided by WGIs, many economists agree that good governance plays an important role in the analysis of the performance across countries [36]. Good governance is an important factor in growing the economy $[37,38]$. Despite this, a number of publications suggest the importance of governance and the necessary institutional conditions. Some researchers consider governance a forecast of growth [39] and the government institutions play a significant part in economic growth $[40,41]$. Some authors refer to effective institutions in formulating the long-term growth, showing that countries with weaker institutions face a crisis and stagnation [42].

Economic growth is directly and indirectly linked to governance $[43,44]$. Good governance promotes economic growth and undermines income inequity. Good governance has gained a lot of importance in recent decades. This importance is growing globally, particularly for developing countries in order to attract more investment and sustainable growth [45]. Poor institutional quality leads to poor political and economic activities that do not encourage the productive activities [40]. As mentioned by [46], economic development not only increases the economic resources but also helps to build institutions. They also include that institutions are the basis to have low corruption, rule of law, etc. Similarly, it can be seen that developed countries are politically more stable than developing or poor countries [47].

Moreover, all six dimensions given by WDIs seem to be correlated with each other and can affect each other. For example, the authors in [48] show that poor governance has an adverse effect on investment. The ineffectiveness of government, weakness of the law and political instability are directly related to corruption, which ultimately make it worse for investment. In addition, economists briefly discuss how these variables are interrelated and affect each other. The weakness in rule of law causes corruption and adversely affects the economy. Poor regulatory quality and poor government policies increase bribery by restricting competition. Therefore, property rights will be less protected and people will feel unprotected against the rule of law because they think their tax money is not well spent [49].

\subsection{Economic Growth, Debt and Governance}

Political economics theory and research show that a certain degree of positive indebtedness is important to the performance of an economy. Thus, earlier research has identified two reasons for this positive influence: one is the fluctuating role of public debt as advocated by Barro [4] while the second reason is the wealth redistributive role of public debt as described by $[50,51]$. Nevertheless, countries with good governance can take advantage of this beneficial aspect. Good governance is regarded as a prerequisite for growth in the economy [39,40]. The work of North [40] describes the significance of institutions, and emphasizes on institutional quality results in encouraging higher investment that leads to economic growth. Moreover, quality institutes prevent distortion activities and reduce uncertainty. Corruption is seen as a factor distorting economic activities by reducing private and foreign direct investment, thereby reducing economic growth [52].

Most researchers analyze debt-governance relationship through political and institutional factors. Governance helps to accumulate public debt [53]. The authors of $[54,55]$ developed the debt theory which stipulates that under same economic conditions, different countries pursue different levels of public debt because of policy decisions and agreements. 
Among the six dimensions of governance presented by Kaufmann, some of the preceding publications address the factor of corruption; for example, the studies of [6,56-60] posit that corruption results in adversely affecting growth. Corruption affects the economy through improper application of government resources, in this case, the government finances mainly through borrowing, resulting in a higher interest rate and burden on the economy. Some public investment can be diverted from their purpose by corrupt individuals [61] as due to these rent-seeking activities, the government invests most of the public expenditure in sectors which are not of importance to the public, such as highways, rather than schools and hospitals [62].

Other than corruption, some earlier publications also account for the impacts of other dimensions of governance on public debt. According to [63], other dimensions of governance might be correlated with one another, improving that rule of law reduces the harms of corruption and protects property rights. Voice and Accountability can enhance a nation's borrowing authority through its integrity [64] and it has a positive relationship with growth [63], as well as improving the ability of debt forgiveness [65]. Political institutions play an important role in financial stability $[66,67]$. Political stability not only improves the legal system of the economy by making the given contracts awarded valid, but also improves the overall macroeconomic stability [68]. Efficient and effective institutions and political stability not only reduce output volatility, but also improve the real GDP growth and reduce the likelihood of a sovereign debt crisis [69]. Moreover, an efficient and effective regulatory system is a key driver of economic performance [46]. The quality of regulation lies in the framework of good governance. The smooth functioning of a regulatory system strengthens investor confidence by balancing the accountability, transparency and consistency [70]. In addition, weak government effectiveness underpins corruption that ultimately affects the macroeconomic stability [71].

On the whole, the invaluable literature implies that governance influences the level of public debt and overall macroeconomic stability. All the six dimensions of governance are somewhat correlated to each other. Weak governance inclines the public debt level through the rent-seeking activities and allocation of government spending.

The objective of this study is to fulfill the gap in previous literature by checking the mediation role of governance in debt-growth relationship. Taking this into account, we explore quality of governance, whether it is high or low and how this impacts the debt-growth relationship or not.

\section{The Model, Estimation Approach and Data}

\subsection{The Model}

In this study, the model begins with a neoclassical growth model. To represent aggregate production function, the neoclassical growth model is considered to be an important framework:

$$
\mathrm{Y}=\mathrm{f}(\mathrm{K}, \mathrm{L})
$$

where $\mathrm{Y}$ indicates total production, $\mathrm{K}$ indicates capital stock and $\mathrm{L}$ represents labor. As the existence of heterogeneity across countries and the analysis of this production function show the different steady states, the concept of convergence arises. According to this model, poor countries grow faster to move to steady-state than countries with higher values because of high return to capital [72,73]. There are different variables to underpin the convergence such as debt hang theory which suggests that if a debt burden of a country is so large that it is impossible to repay, then this divergence dissuades current investment. Consequently, this slows the economic growth and makes it difficult for the economy to recover. As underpinned by [74], debt-growth relationship is explained as inverted U-shaped. However, as discussed by [75], we add the public debt (D) into our model. Here, $D$ is the public debt to GDP ratio. Equation (1) takes the form $Y=f(K, L, D)$. Evidence from cross-country analysis shows that, at the time, some developing countries are growing more rapidly by taking the advantage of catching up, while at the same time, other developing 
countries are growing slowly. The model specification below measures how public debt affects economic growth:

$$
\mathrm{y}_{\mathrm{it}}=\alpha+\beta_{\mathrm{it}}+\gamma \mathrm{X}_{\mathrm{it}}+\rho_{\mathrm{it}}+\varepsilon_{\mathrm{it}}
$$

where $\alpha, \beta$ and $\gamma$ are the coefficients of elasticity. Governance is one of the reasons countries have different growth levels [76]. In the previous literature, researchers seek the direct linkage between governance and growth. Results show that governance and economic growth are positively correlated [77-79]. Different authors well documented governance influence on economic growth and their analytical framework shows the growth regression equation. In our analysis, following [80], we measure debt-growth relationship by taking governance as a mediating variable. Moreover, we use all six governance indicators as explained by WGIs, whereas they use only one indicator of governance (control of corruption). We also use the expression of interaction between debt and governance to measure the marginal effect. After induction of governance variable, our model transforms into the following form:

$$
\operatorname{lny}_{\mathrm{it}}=\beta_{0}+\beta_{1} \operatorname{lndebt}_{\mathrm{it}}+\beta_{2} \operatorname{gov}_{\mathrm{it}}+\beta_{3} \operatorname{lndebt}_{\mathrm{it}} \times \operatorname{gov}_{\mathrm{it}}+\gamma \mathrm{X}_{\mathrm{it}}+\rho_{\mathrm{it}}+\varepsilon_{\mathrm{it}}
$$

where i represents countries involved in our study and $t$ is the timeframe. In our analysis $(i=1, \ldots, 106$ and $t=1996, \ldots, 2015)$, whereas, gov $_{i t}$ is the set of governance variable, $\rho_{i t}$ represents country's specific fixed effects and $\varepsilon_{i t}$ denotes error term. In our analysis, vector $\mathrm{X}_{\mathrm{it}}$ comprises of a set of control variables such as total factor productivity (TFP); inflation; government size and exports (EXP). TFP contributes positively to economic growth [81] whereas exports of country raise productivity, and hence contributes positively to economic growth [75]. Inflation is measured by GDP deflator and has an adverse effect on economic growth [82]. Government size is the government consumption expenditure and it also has a negative effect on economic growth [72]. As our main goal is to measure the mediating role of governance in debt-growth relationship, therefore, the marginal impact of public debt can be computed from the equation below:

$$
\frac{\partial \ln y_{\text {it }}}{\partial \operatorname{lndebt} t_{\text {it }}}=\beta_{1}+\beta_{3} \text { gov }_{\text {it }}
$$

The preceding equation clearly demonstrates that the marginal impact of public debt on economic growth depends on governance. This means marginal effect between countries is not homogeneous, but is dependent on a country's governance. In the countries where governance level is low (bad), the marginal effect seems to be worsening. Moreover, this negative effect decreases in countries where the level of governance is high (good).

\subsection{Estimation Approach}

\subsubsection{Panel Unit Root Test}

In this study, we start with panel unit root tests in order to identify the issue of heterogeneity because the main difference between times series and panel data is heterogeneity. In time series, the heterogeneity is considered a problem as the unit root is tested in a given model for a given individual or country. As far as the panel is concerned, this heterogeneity must be checked. For this purpose, we employ MW-augmented Dickey-Fuller and MW-PP unit root tests for panel data.

\subsubsection{Static Panel Least Square Dummy Variable and System GMM Estimations}

In our current article, we use the sample of 106 economies worldwide covering the period 1996-2015 in order to study the impact of public debt on economic growth. Our main contribution is incorporating interaction term between public debt and the governance in order to show that the relationship between these two variables is conditioned by the quality of governance. According to previous literature, since ordinary least square (OLS) estimation is likely to be a source of biasedness, if there exists simultaneity, growth can generate the problem of endogeneity, since economic growth affects some explanatory 
variables such as governance. Conversely, without simultaneity, OLS estimation is efficient and consistent. In case where simultaneity is present, then (2SLS) instrumental variables techniques and generalized method of moments (GMM) are used. These two estimators are considered to be more consistent and efficient. This simultaneity produces biased results and can be corrected using various econometric models. To address this problem, the Hausman [83] test is widely applied. We perform this test by selecting alternate estimation techniques rather than OLS. We first perform the Hausman test to verify the appropriate alternative between fixed and random effect. FE seems to be more appropriate than RE. In addition, the previous literature suggests that we cannot rely solely on the FE method because the problem of endogeneity may still exist, such as public debt may be related to residuals and the unobserved country-specific factors. Thus, based on previous literature, we conclude that GMM estimation technique is appropriate for dealing with the problem of endogeneity.

Hence, we use both the GMM in first difference developed by Arellano and Bond [84] and GMM in system developed by Blundell and Bond [85]. GMM in first difference has widely been used in dynamic panel data estimation. This estimation technique applies the first difference and an appropriate level of their lagged value. The specific effects eliminate in this way. However, the GMM in first difference becomes inappropriate in case of a small number of observations in time series and the process can be improved by applying system GMM [84]. The system GMM is considered as being more efficient compared to first difference GMM. The system GMM estimation not only eliminates a country's specific effect but also controls the problem of endogeneity by using lagged values of dependent variables.

We use the Sargan [86] test to verify the validity of over-identification of instrument, testing the validity of null hypothesis whether the error term is correlated. It is suggested that GMM is an appropriate estimation technique to solve the common problems in growth model, especially, by using the first difference to remove time-invariant country- specific effects. Running the system GMM attains the following equation form:

$$
\ln y_{i t}=\alpha_{i}+\beta \ln y_{i, t-1}+\delta X_{i t}+\vartheta_{i}+\varepsilon_{i t}
$$

The Equation (5) takes the below form for GMM in difference:

$$
\ln y_{i t}-\ln y_{i t-1}=\alpha_{i}+\beta\left(\operatorname{lny}_{i, t-1}-\ln y_{i, t-2}\right)+\delta\left(X_{i t}-X_{i t-1}\right)+\left(\vartheta_{i}-\vartheta_{i-1}\right)+\left(\varepsilon_{i t}-\varepsilon_{i, t-1}\right)
$$

GMM in difference estimation allows us to exclude country-specific effects and introduce the new error term [84]. The new error term supports the assumption that the error term $\varepsilon_{i t}$ has no correlation and the predictors are exogenous. In our analysis, we use two-step system GMM estimation to better understand short-term effect.

\subsection{The Data}

The data used in this study are drawn from the database of the World Bank, IMF, PINN World Table (version 9.1) and Worldwide Governance Indicators. Depending on availability, it comprises the period from 1996 until 2015 for 106 countries (list of countries is shown in Appendix A (Table A1). In addition, for robustness checking, we also use International Country Risk Guide (ICRG) dataset. The definitions and sources of data, and descriptive statistics are presented in Tables 1 and 2 respectively. The dependent variable in this paper is per capita GDP. Public debt is the independent variable and is defined as the central government debt (which represents over $90 \%$ of total government debt). 
Table 1. Definitions and data sources of variables.

\begin{tabular}{|c|c|c|}
\hline Variables & Description & Data Source \\
\hline Yi,t & It represents the real GDP per capita. & WDI \\
\hline DEBT & $\begin{array}{l}\text { It represents public debt to GDP ratio. Here, debt means the } \\
\text { general government gross debt. }\end{array}$ & IMF \\
\hline GOV & $\begin{array}{l}\text { We use all six measures of governance and make a composite } \\
\text { index ranging from } 0-10 .\end{array}$ & $\begin{array}{c}\text { WDI } \\
\text { (World Governance Indicators) }\end{array}$ \\
\hline ICRG & $\begin{array}{l}\text { This dataset consists of } 100 \text { points distributed among } 12 \\
\text { variables on the basis of social and political factors, each } \\
\text { variable has different points. Out of } 12 \text { variables, } 5 \text { variables } \\
\text { have } 12 \text { points such as government stability, socioeconomic } \\
\text { conditions, investment profile, internal conflicts and external } \\
\text { conflict; } 6 \text { variables have } 6 \text { points such as corruption, military in } \\
\text { politics, religious tensions, law and order, ethnic tensions and } \\
\text { democratic accountability, whereas bureaucracy quality has } 4 \\
\text { points. If the commutative value is less than } 50 \% \text {, it means high } \\
\text { risk. Greater the value, lower the risk. We make a composite } \\
\text { index ranging from } 0-10 .\end{array}$ & $\begin{array}{l}\text { International Country Risk Guide dataset } \\
\text { (ICRG) }\end{array}$ \\
\hline TFP & Refers to total factor productivity. & PINN WORLD TABLE 9.1 \\
\hline INF & $\begin{array}{c}\text { Refers to inflation, which is measured as the annual rate of } \\
\text { change in GDP deflator. }\end{array}$ & WDI \\
\hline GS & Refers to general government spending as a share of GDP. & PINN WORLD TABLE 9.1 \\
\hline EXP & Refers to total exports presented as share of GDP. & PINN WORLD TABLE 9.1 \\
\hline
\end{tabular}

Table 2. Descriptive statistics.

\begin{tabular}{cccccc}
\hline Variable & Obs. & Mean & Std. Dev. & Min & Max \\
\hline GDP & 2120 & $13,555.75$ & $18,148.56$ & 112.8494 & $119,225.4$ \\
\hline PUBLIC DEBT & 2120 & 0.5589 & 0.4050 & 0.0006 & 3.4267 \\
\hline TFP & 2120 & 0.6343 & 0.2533 & 0.0986 & 1.9926 \\
\hline INFLATION & 2120 & 8.2680 & 27.5666 & -31.5959 & 779.4702 \\
\hline GOVERNMENT SIZE & 2120 & 0.0764 & 0.0764 & 0.0166 & 0.6949 \\
\hline EXPORTS & 2120 & 0.3058 & 0.3058 & 0.0016 & 2.5675 \\
\hline GOVERNANCE & 2120 & 1.8706 & 1.8706 & 1.21 & 9.01 \\
\hline ICRG & 1840 & 6.9673 & 1.2591 & 3.1920 & 9.4670 \\
\hline
\end{tabular}

Notes: Missing values are replaced by mean value.

The governance dataset consists of 6 variables: voice and accountability, political stability and violence, government effectiveness, rule of law, regulatory quality, and control of corruption as described by [87]. The governance dataset variables are defined on a -2.5 to 2.5 scale; greater values correspond to better governance. Previous literature shows that some authors use different ways to create index for governance. Some authors use the governance variables without any modification as given by Worldwide Governance Indicators $[13,14,88]$. To deal with the issue of causality, for example, authors in [89] use the simple average of the six indicators of governance to modify a new index. Whereas some authors use percentile rank to index governance variable ranges from 0 to 1 , better value means better the quality of governance [90]. Some authors, such as [11], use statistical method of principal component factor analysis (PCA) for constructing a composite governance index. In this paper, we construct a percentile rank with index ranges from $0-10$ by using all six indicators of governance. For this purpose, first of all, we take the mean of all six measures of governance and then we add 2.5 in mean value and multiply it with 2.

The descriptive statistics of variables used in this analysis is provided in Table 2. Governance and ICRG variables are ranging from 1.2 to 9.01 and 3.192 to 9.467 respectively. For governance value, greater value means quality of governance is better and lower value 
means vice versa. For ICRG variable, if the value is less than $50 \%$, it means the country is at high risk. Ranging from $61-70 \%$ means moderate risk, from $71-80 \%$ means low risk. If value exceeds $80 \%$, this shows very low risk. Moreover, while we use ICRG variable, 14 countries are not included in the analysis because of the unavailability of the data, and therefore, the number of countries becomes 92. The debt to GDP ratio has a mean of 0.5589 , therefore, it seems that the gap between the minimum and maximum value of debt to GDP ratio is very large. The distortion of debt to GDP ratio therefore varies considerably. The correlation matrix for variables used in our estimation is provided in Appendix A (Tables A2 and A3).

\section{Results and Discussion}

\subsection{Results of Panel Unit Root Test}

The results of panel unit root test suggest that all the variables are non-stationary in their level and they become stationary at first difference in both MW (ADF) test and MW (PP) test. The null hypothesis in both cases is all panels contain unit roots; our results reject the null hypothesis and accept the alternate hypothesis of at least one panel is stationary. Therefore, from the results in Table 3, we conclude that all series of variables is stationary at first difference.

Table 3. Panel unit root test results.

\begin{tabular}{ccccccccc}
\hline \multirow{2}{*}{ Variables } & \multicolumn{4}{c}{ aDF } & \multicolumn{2}{c}{ PP } \\
\cline { 2 - 9 } & Statistic & Prob. & Statistic & Prob. & Statistic & Prob. & Statistic & Prob. \\
\cline { 2 - 9 } & 83.1710 & 1.0000 & 618.3302 & 0.0000 & 60.6679 & 1.0000 & 760.9305 & 0.0000 \\
\hline Y & 215.3464 & 0.4231 & 589.1298 & 0.0000 & 200.9820 & 0.6957 & 931.1289 & 0.0000 \\
\hline debt & 151.3765 & 0.9994 & 278.0759 & 0.0016 & 163.5261 & 0.8862 & 240.6634 & 0.0086 \\
\hline gov & 138.9459 & 1.0000 & 372.4569 & 0.0000 & 57.8912 & 1.0000 & 430.4834 & 0.0000 \\
\hline inf & 108.6041 & 1.0000 & 823.2310 & 0.0000 & 138.8481 & 1.0000 & 1197.9083 & 0.0000 \\
\hline gs & 210.3000 & 0.5201 & 1086.6427 & 0.0000 & 238.6427 & 0.2210 & 2020.2153 & 0.0000 \\
\hline exp & 218.9263 & 0.3222 & 1104.1247 & 0.0000 & 138.8481 & 1.0000 & 2075.0177 & 0.0000 \\
\hline
\end{tabular}

\subsection{LSDV and System GMM Results}

The objective of this paper is to study the relationship between public debt and economic growth conditioned by governance in sample countries. In our analysis, we adopt a step-wise method to treat the potential endogenous problem. Firstly, we apply lags on right-hand variables, then incorporate the FE through our regression and then we apply the IV approach as this approach is useful in addressing the endogeneity problem. Although, the IV approach is useful for treating the endogeneity problem but the main problem with IV approach is to find the suitable instruments associated with the exogenous variables and are not associated with the error terms. At the end, we use the system GMM estimation to check robustness of our results. In applying the system GMM estimator, different lags can be applied in order to measure the causality. Results are different with different lags [91]. The main reason behind using more than one lag is there might be serial correlation error term still remaining. That is, the Arellano-Bond AR-2 is rejecting the null hypothesis of second order serial correlation of the first differenced error term. In this scenario, the better idea is to include further lags of the dependent variable. In applying system GMM estimator, higher order autoregressive lags can capture the serial correlation in the error. This problem can be solved by using deeper lags as instrument. First of all, we apply the lags of one to four years on the dependent variable depending on the significant values. 
Table 4 provides results for the effect of governance on debt-growth nexus using static panel LSDV in first two columns and two-step system GMM in last two columns. In column 1, public debt and governance are included and the results show that public debt has negative and significant impact on economic growth, while governance also has negative and significant impact on economic growth because in our model, most of the countries have low level of governance.

Table 4. Estimate results of Panel LSDV and two-step system GMM: effects of public debt on GDP growth (1996-2015).

\begin{tabular}{|c|c|c|c|c|}
\hline & 1 & 2 & 3 & 4 \\
\hline Yit & FE & FE & GMM & GMM \\
\hline yit -1 & & & $\begin{array}{c}0.9033 * * * \\
(0.0047)\end{array}$ & $\begin{array}{l}0.9283 * * * \\
(0.0079)\end{array}$ \\
\hline yit-2 & & & $\begin{array}{c}-0.1588^{* * *} \\
(0.0057)\end{array}$ & $\begin{array}{l}-0.1857^{* * *} \\
(0.0070)\end{array}$ \\
\hline yit-3 & & & $\begin{array}{c}0.1213^{* * *} \\
(0.0032)\end{array}$ & $\begin{array}{l}0.2203^{* * *} \\
(0.0068)\end{array}$ \\
\hline yit -4 & & & $\begin{array}{c}-0.0293^{* * * *} \\
(0.0035)\end{array}$ & $\begin{array}{l}-0.1314^{* * *} \\
(0.0073)\end{array}$ \\
\hline Gov & $\begin{array}{c}-0.1085^{* * *} \\
(0.0248)\end{array}$ & $\begin{array}{l}-0.0372 \\
(0.0253)\end{array}$ & $\begin{array}{c}-0.0262^{* * * *} \\
(0.0013)\end{array}$ & $\begin{array}{c}0.0232 * * * \\
(0.0030)\end{array}$ \\
\hline Debt & $\begin{array}{c}-0.2863 \text { *** } \\
(0.0199)\end{array}$ & $\begin{array}{c}-0.7448^{* * *} \\
(0.0515)\end{array}$ & $\begin{array}{c}-0.2028^{* * *} \\
(0.0043)\end{array}$ & $\begin{array}{l}-0.3318^{* * *} \\
(0.0088)\end{array}$ \\
\hline debt $\times$ gov & & $\begin{array}{c}0.0910^{* * *} \\
(0.0095)\end{array}$ & & $\begin{array}{c}0.0395^{* * *} \\
(0.0014)\end{array}$ \\
\hline Tfp & $\begin{array}{l}0.9432 * * * \\
(0.0587)\end{array}$ & $\begin{array}{l}0.8593^{* * * *} \\
(0.0579)\end{array}$ & $\begin{array}{l}0.0866^{* * *} \\
(0.0110)\end{array}$ & $\begin{array}{c}0.1361^{* * * *} \\
(0.0128)\end{array}$ \\
\hline $\operatorname{Inf}$ & $\begin{array}{c}-0.1216^{* * *} \\
(0.0097)\end{array}$ & $\begin{array}{c}-0.1104^{* * * *} \\
(0.0095)\end{array}$ & $\begin{array}{c}0.0228^{* * * *} \\
(0.0009)\end{array}$ & $\begin{array}{l}0.0244^{* * *} \\
(0.0009)\end{array}$ \\
\hline Gs & $\begin{array}{c}0.2222^{* * *} \\
(0.0440)\end{array}$ & $\begin{array}{c}0.1942^{* * *} \\
(0.0430)\end{array}$ & $\begin{array}{c}-0.0686^{* * *} \\
(0.0057)\end{array}$ & $\begin{array}{c}-0.0296^{* * *} \\
(0.0107)\end{array}$ \\
\hline Exp & $\begin{array}{l}0.5629 * * * \\
(0.0292)\end{array}$ & $\begin{array}{c}0.5381^{* * *} \\
(0.0286)\end{array}$ & $\begin{array}{c}0.1649^{* * *} \\
(0.0057)\end{array}$ & $\begin{array}{c}0.1648^{* * *} \\
(0.0097)\end{array}$ \\
\hline Constant & $\begin{array}{c}10.7785^{* * *} \\
(0.1777)\end{array}$ & $\begin{array}{c}10.2764^{* * *} \\
(0.1811)\end{array}$ & $\begin{array}{l}1.5592^{* * * *} \\
(0.0429)\end{array}$ & $\begin{array}{l}1.4957^{* * * *} \\
(0.0577)\end{array}$ \\
\hline Observations & 1925 & 1925 & 1366 & 1366 \\
\hline R-squared & 0.4112 & 0.4398 & & \\
\hline Number of countries & 106 & 106 & 106 & 106 \\
\hline $\begin{array}{l}\text { Sargan test } \\
p \text {-value }\end{array}$ & & & $\begin{array}{c}103.7508 \\
1.0000\end{array}$ & $\begin{array}{c}100.9895 \\
0.8029\end{array}$ \\
\hline $\begin{array}{l}\text { First-order serial } \\
\text { correlation }\end{array}$ & & & -4.38 & -4.3769 \\
\hline$p$-value & & & 0.0000 & 0.0000 \\
\hline $\begin{array}{l}\text { Second-order serial } \\
\text { correlationd }\end{array}$ & & & -0.56519 & 0.72125 \\
\hline$p$-value & & & 0.5719 & 0.4708 \\
\hline
\end{tabular}

Notes: First two columns provide the results of LSDV and last two columns provide the results of dynamic two-step system GMM mean to estimate the effect of public debt on GDP growth using WGIs dataset. *** is significant at the $1 \%$ level.

These findings conform to previous literature, such as [92-94], whereas $[38,95,96]$ report the adverse effect of bad governance. Column 2 provides the interaction term between public debt and economic growth. Our findings show that the public debt is a function of governance. A country's debt level is accumulated at the governance level and public debt has a negative effect on economic growth; these results are consistent with previous studies. The overall effect is determined by the Equation (4), which shows that public debt and economic growth has a negative and significant relationship when the 
threshold value of governance is below 8.18. Similarly, debt has positive influence when the value of a country's governance is higher than the threshold value.

In Table 4, columns 3 and 4 provide the results of dynamic system GMM estimation used in this paper as a benchmark for checking the robustness of FE estimation. Column 3 presents results without interactive term. In column 3, public debt and governance coefficients are negative and significant which show the consistency with previous studies as we explained earlier. Column 4 presents the results of interaction term between public debt and economic growth; the result shows that the debt negatively impacts economic growth when a country has low governance level and debt boosts a country's growth when governance level is high. The threshold level of debt from negative to positive is 8.4. This shows that debt-growth relationship is negative when the governance value is below 8.4; similarly, a positive and significant relationship whenever a country's governance value is above 8.4. Moreover, if we take the estimation results of column 4 , we can calculate the critical and marginal values of each country in the sample as countries across have different levels of governance. According to the results of two-step system GMM, if all other things are unchanged, the marginal effect can be calculated as $(-0.3318+0.0395 \times$ gov $)$. On the basis of mean, minimum and maximum value of governance, we calculate the marginal effect becomes $-0.1183,-0.2840$ and 0.0241 respectively. This shows that the extent to which marginal effects change between countries is dependent on the level of governance.

Moreover, in our analysis, we conduct the Sargan-Hansen test of over-identifying restrictions and the Arellano-Bond test for zero autocorrelation in first-difference test of autocorrelation to check the validity of instruments. Results of Sargan-Hansen test clearly show that we cannot reject the null hypothesis as $p$-value is a long way away from the indicated problems with the instruments. Therefore, this supports the validity of these instrument variables. Moreover, Arellano-Bond test indicates that the first order is serially correlated and is rejected while the output result of second order shows that there is no serial correlation.

\subsection{Robustness Check}

This section reports the robustness of our estimation results.

\subsubsection{Using Alternate Proxy of Governance Variable}

First, we include ICRG dataset that can be used as a proxy of governance as it is used in most of the previous literature, for example [11,97]. Table 5 provides estimation results of alternate proxy use for governance variable. We use the ICRG dataset as a proxy to measure governance. These results can be seen to be almost identical to the results of estimation using WGIs dataset. It can be seen from estimation results presented in Table 4 that there is consistency in our main results which confirms intermediating role of governance in debt-growth relationship. Our estimation results show that public debt is positively impacting economic growth due to higher (good) level of governance.

Moreover, the threshold value separating negative and positive impact of public debt is calculated using Equation (4). In case of static panel LSDV estimation, the threshold is 8.76 and in case of two-step system GMM, the value of threshold is 8.74. This means that governance level needs to be higher if public debt is to positively affect economic growth. As two-step system GMM is a benchmark in this paper, we consider the results of two-step system GMM. Hence the estimation results using ICRG show that if all other things remain unchanged, an increase of one point in the level of governance leads to an increase in GDP per capita by (slope $=-0.5797+0.063 \times$ gov). Therefore, the minimum threshold level ( $g$ ov $=8.74$ ) is required for public debt to be positive. 
Table 5. Robustness test: estimate results of Panel LSDV, and two-step system GMM estimates: effects of public debt on GDP growth (1996-2015).

\begin{tabular}{|c|c|c|c|c|}
\hline & 1 & 2 & 3 & 4 \\
\hline Yit & FE & FE & GMM & GMM \\
\hline yit-1 & & & $\begin{array}{c}0.8582^{* * *} \\
(0.0068)\end{array}$ & $\begin{array}{c}0.8354^{* * *} \\
(0.0099)\end{array}$ \\
\hline yit-2 & & & $\begin{array}{c}-0.1086^{* * *} \\
(0.0064)\end{array}$ & $\begin{aligned}- & 0.1169^{* * * *} \\
& (0.0071)\end{aligned}$ \\
\hline yit-3 & & & $\begin{array}{c}0.0909^{* * * *} \\
(0.0038)\end{array}$ & $\begin{array}{l}0.1998^{* * * *} \\
(0.0056)\end{array}$ \\
\hline yit -4 & & & $\begin{array}{c}-0.0223^{* * *} \\
(0.0071)\end{array}$ & $\begin{aligned}- & 0.0865^{* * * *} \\
& (0.0092)\end{aligned}$ \\
\hline Icrg & $\begin{array}{c}-0.1800^{* * *} \\
(0.0234)\end{array}$ & $\begin{array}{c}-0.0775^{* * *} \\
(0.0258)\end{array}$ & $\begin{array}{l}0.0193 * * * \\
(0.0051)\end{array}$ & $\begin{array}{l}0.0948^{* * *} \\
(0.0078)\end{array}$ \\
\hline Debt & $\begin{array}{c}-0.2628^{* * *} \\
(0.0203)\end{array}$ & $\begin{array}{c}-1.1201^{* * *} \\
(0.1016)\end{array}$ & $\begin{array}{c}-0.1789 * * * \\
(0.0068)\end{array}$ & $\begin{aligned}- & 0.5797^{* * * *} \\
& (0.0287)\end{aligned}$ \\
\hline debt $\times$ icrg & & $\begin{array}{c}0.1278^{* * *} \\
(0.0149)\end{array}$ & & $\begin{array}{c}0.0663^{* * *} \\
(0.0036)\end{array}$ \\
\hline Tfp & $\begin{array}{l}0.9332 * * * \\
(0.0639)\end{array}$ & $\begin{array}{l}0.8314^{* * *} \\
(0.0635)\end{array}$ & $\begin{array}{c}0.1248^{* * *} \\
(0.0180)\end{array}$ & $\begin{array}{c}0.1418^{* * *} \\
(0.0403)\end{array}$ \\
\hline Inf & $\begin{array}{c}-0.0991^{* * * *} \\
(0.0101)\end{array}$ & $\begin{array}{c}-0.0880^{* * * *} \\
(0.0099)\end{array}$ & $\begin{array}{c}0.0184^{* * * *} \\
(0.0011)\end{array}$ & $\begin{array}{c}0.0196^{* * *} \\
(0.0012)\end{array}$ \\
\hline Gs & $\begin{array}{l}0.2231^{* * *} \\
(0.0504)\end{array}$ & $\begin{array}{l}0.1542 * * * \\
(0.0499)\end{array}$ & $\begin{array}{c}-0.0835^{* * *} \\
(0.0092)\end{array}$ & $\begin{aligned}-0.0868^{* * *} \\
(0.0189)\end{aligned}$ \\
\hline Exp & $\begin{array}{l}0.7095^{* * *} \\
(0.0340)\end{array}$ & $\begin{array}{c}0.6916^{* * *} \\
(0.0333)\end{array}$ & $\begin{array}{c}0.2967^{* * *} \\
(0.0092)\end{array}$ & $\begin{array}{c}0.3240 * * * \\
(0.0107)\end{array}$ \\
\hline Constant & $\begin{array}{c}11.6922 * * * \\
(0.1960)\end{array}$ & $\begin{array}{c}10.7954^{* * *} \\
(0.2181)\end{array}$ & $\begin{array}{c}1.6490 * * * \\
(0.0958)\end{array}$ & $\begin{array}{c}1.1037^{* * *} \\
(0.1450)\end{array}$ \\
\hline $\begin{array}{l}\text { Observations } \\
\text { R-squared }\end{array}$ & $\begin{array}{c}1665 \\
0.4512\end{array}$ & $\begin{array}{l}1665 \\
0.4760\end{array}$ & 1181 & 1181 \\
\hline $\begin{array}{l}\text { Number of } \\
\text { countries }\end{array}$ & 92 & 92 & 92 & 92 \\
\hline $\begin{array}{l}\text { Sargan test } \\
p \text {-value }\end{array}$ & & & $\begin{array}{c}90.28598 \\
1.0000\end{array}$ & $\begin{array}{c}87.73857 \\
0.9678\end{array}$ \\
\hline $\begin{array}{l}\text { First-order serial } \\
\text { correlation }\end{array}$ & & & -4.1098 & -4.0877 \\
\hline$p$-value & & & 0.0000 & 0.0000 \\
\hline $\begin{array}{l}\text { Second-order } \\
\text { serial correlation }\end{array}$ & & & -1.2407 & 1.2407 \\
\hline$p$-value & & & 0.2147 & 0.7400 \\
\hline
\end{tabular}

Notes: First two columns provide the results of LSDV and last two columns provide the results of dynamic two-step system GMM mean to estimate the effect of public debt on GDP growth using ICRG dataset. ${ }^{* * *}$ is significant at the $1 \%$ level.

Similarly, as in the previous section, the validity of instrument variables is checked by Sargan-Hansen test of over-identifying restrictions and the Arellano-Bond test for zero autocorrelation in first-difference test of autocorrelation. Results of Sargan-Hansen test clearly support the validity of instruments and Arellano-Bond test indicates that the first order AR is serially correlated and is rejected but the second order AR cannot be rejected. The results suggest that the impact of public debt on economic growth depends on the governance level in sample countries. Countries with higher governance level experience lesser adverse effect of public debt. 
4.3.2. Using 3-Years Non-Overlapping Averaged Estimates to Verify Our Results (in Case of WGIs as Proxy of Governance Variable)

We use the averaged variables to measure the long-run effects. For this purpose, we use a three-year averaged model. We averaged our model of 20 years into 7 nonoverlapping periods; first six periods consist of 3-years non-overlapping periods while the last period consists of 2-years non-overlapping period. Table 6 provides the estimation results of three-year averaged model using WGIs dataset as a proxy to measure governance. The results are consistent and validate our estimation results as presented in full sample (see Table 4).

Table 6. Robustness test: 3-years non-overlapping averaged estimates of Panel LSDV and two-step system GMM estimates: effects of public debt on GDP growth (1996-2015).

\begin{tabular}{|c|c|c|c|c|}
\hline & 1 & 2 & 3 & 4 \\
\hline Yit & FE & FE & GMM & GMM \\
\hline yit-1 & & & $\begin{array}{l}0.7321^{* * *} \\
(0.0161)\end{array}$ & $\begin{array}{l}0.6948^{* * *} \\
(0.0165)\end{array}$ \\
\hline yit -2 & & & $\begin{array}{l}-0.0207 \\
(0.0180)\end{array}$ & $\begin{array}{l}-0.0239 \\
(0.0185)\end{array}$ \\
\hline yit-3 & & & $\begin{array}{c}-0.1668^{* * * *} \\
(0.0149)\end{array}$ & $\begin{array}{c}-0.1198^{* * *} \\
(0.0119)\end{array}$ \\
\hline gov & $\begin{array}{c}-0.1590^{* * *} \\
(0.0480)\end{array}$ & $\begin{array}{l}-0.0782 \\
(0.0477)\end{array}$ & $\begin{array}{l}0.0563^{* * * *} \\
(0.0150)\end{array}$ & $\begin{array}{l}0.1067^{* * * *} \\
(0.0152)\end{array}$ \\
\hline debt & $\begin{array}{c}-0.2967 * * * \\
(0.0357)\end{array}$ & $\begin{array}{c}-0.8605^{* * *} \\
(0.0892)\end{array}$ & $\begin{array}{c}-0.1060^{* * *} \\
(0.0136)\end{array}$ & $\begin{array}{c}-0.3373^{* * * *} \\
(0.0287)\end{array}$ \\
\hline debt $\times$ gov & & $\begin{array}{l}0.1099 * * * \\
(0.0160)\end{array}$ & & $\begin{array}{l}0.0393 * * * \\
(0.0037)\end{array}$ \\
\hline $\mathrm{tfp}$ & $\begin{array}{l}1.2606^{* * *} \\
(0.1860)\end{array}$ & $\begin{array}{l}1.1578^{* * *} \\
(0.1798)\end{array}$ & $\begin{array}{c}0.0837 \\
(0.0517)\end{array}$ & $\begin{array}{l}0.1583^{* * *} \\
(0.0420)\end{array}$ \\
\hline Inf & $\begin{array}{c}-0.2124^{* * * *} \\
(0.0193)\end{array}$ & $\begin{array}{c}-0.1929 * * * \\
(0.0188)\end{array}$ & $\begin{array}{l}0.0107^{* * * *} \\
(0.0025)\end{array}$ & $\begin{array}{l}0.0113^{* * * *} \\
(0.0023)\end{array}$ \\
\hline Gs & $\begin{array}{l}0.8129 * \\
(0.4328)\end{array}$ & $\begin{array}{l}0.7186^{*} \\
(0.4170)\end{array}$ & $\begin{array}{c}-0.7836^{* * * *} \\
(0.1215)\end{array}$ & $\begin{array}{c}-0.6288^{* * *} \\
(0.0927)\end{array}$ \\
\hline Exp & $\begin{array}{c}0.6579 * * * \\
(0.0569)\end{array}$ & $\begin{array}{c}0.6197 * * * \\
(0.0551)\end{array}$ & $\begin{array}{c}0.0577^{* * * *} \\
(0.0133)\end{array}$ & $\begin{array}{l}0.0554^{* * *} \\
(0.0099)\end{array}$ \\
\hline Constant & $\begin{array}{l}9.4842^{* * *} \\
(0.2977)\end{array}$ & $\begin{array}{l}9.0775^{* * *} \\
(0.2928)\end{array}$ & $\begin{array}{c}3.7954^{* * *} \\
(0.1031)\end{array}$ & $\begin{array}{l}3.3903^{* * *} \\
(0.1111)\end{array}$ \\
\hline $\begin{array}{l}\text { Observations } \\
\text { R-squared }\end{array}$ & $\begin{array}{c}699 \\
0.4304\end{array}$ & $\begin{array}{c}699 \\
0.4726\end{array}$ & 292 & 292 \\
\hline $\begin{array}{l}\text { Number of } \\
\text { countries }\end{array}$ & 106 & 106 & 104 & 104 \\
\hline $\begin{array}{l}\text { Sargan test } \\
p \text {-value }\end{array}$ & & & $\begin{array}{c}75.57759 \\
0.2471\end{array}$ & $\begin{array}{c}80.52486 \\
0.3395\end{array}$ \\
\hline $\begin{array}{l}\text { First-order serial } \\
\text { correlation }\end{array}$ & & & -3.8804 & -3.7042 \\
\hline$p$-value & & & 0.0001 & 0.0002 \\
\hline $\begin{array}{l}\text { Second-order } \\
\text { serial correlation }\end{array}$ & & & 0.0002 & 0.63576 \\
\hline$p$-value & & & 0.3278 & 0.5249 \\
\hline
\end{tabular}

Notes: First two columns provide 3-years averaged results of LSDV and last two columns provide the results of dynamic two-step system GMM mean to estimate the effect of public debt on GDP growth using WGIs dataset. *** and ${ }^{*}$ are significant at the $1 \%$ and $10 \%$ levels respectively. 
4.3.3. Using 3-Years Non-Overlapping Averaged Estimates to Verify Our Results (in Case of ICRG as Proxy for Governance Variable)

In this section, we check robustness by averaging variables to measure the long-run effects. For this purpose, we use a three-year averaged model. We averaged our model of 20 years into 7 non-overlapping periods; same as done in the previous section; first six periods consist of 3-years non-overlapping periods while the last period consists of 2-years non-overlapping period. Table 7 provides the estimation results of three-year averaged model using ICRG dataset as a proxy to measure governance. In this case, estimation results are consistent with full sample.

Table 7. Robustness test: 3-years non-overlapping averaged estimates of Panel LSDV and two-step system GMM estimation: effects of public debt on GDP growth (1996-2015).

\begin{tabular}{|c|c|c|c|c|}
\hline & 1 & 2 & 3 & 4 \\
\hline Yit & FE & FE & GMM & GMM \\
\hline yit -1 & & & $\begin{array}{c}0.7399 * * * \\
(0.0120)\end{array}$ & $\begin{array}{c}0.7289 * * * \\
(0.0052)\end{array}$ \\
\hline yit-2 & & & $\begin{array}{c}-0.0648^{* * * *} \\
(0.0134)\end{array}$ & $\begin{array}{c}-0.0729^{* * * *} \\
(0.0073)\end{array}$ \\
\hline yit-3 & & & $\begin{array}{c}-0.1770 \text { *** } \\
(0.0116)\end{array}$ & $\begin{array}{c}-0.1355^{* * *} \\
(0.0057)\end{array}$ \\
\hline icrg & $\begin{array}{c}-0.3486^{* * *} \\
(0.0447)\end{array}$ & $\begin{array}{c}-0.1738^{* * *} \\
(0.0472)\end{array}$ & $\begin{array}{c}-0.0657^{* * *} \\
(0.0101)\end{array}$ & $\begin{array}{c}0.0464^{* * *} \\
(0.0108)\end{array}$ \\
\hline debt & $\begin{array}{c}-0.2124^{* * *} \\
(0.0358)\end{array}$ & $\begin{array}{c}-1.5974 * * * \\
(0.1707)\end{array}$ & $\begin{array}{c}-0.1113^{* * *} \\
(0.0074)\end{array}$ & $\begin{array}{c}-0.5856^{* * *} \\
(0.0274)\end{array}$ \\
\hline debt $\times$ icrg & & $\begin{array}{c}0.2034^{* * *} \\
(0.0246)\end{array}$ & & $\begin{array}{c}0.0696^{* * *} \\
(0.0039)\end{array}$ \\
\hline $\mathrm{tfp}$ & $\begin{array}{l}1.9257^{* * *} \\
(0.2272)\end{array}$ & $\begin{array}{l}1.5851^{* * *} \\
(0.2182)\end{array}$ & $\begin{array}{l}0.1193 * * * \\
(0.0365)\end{array}$ & $\begin{array}{l}0.2014^{* * *} \\
(0.0226)\end{array}$ \\
\hline $\operatorname{Inf}$ & $\begin{array}{c}-0.0063^{* * *} \\
(0.0009)\end{array}$ & $\begin{array}{c}-0.0051^{* * * *} \\
(0.0009)\end{array}$ & $\begin{array}{l}0.0033^{* * *} \\
(0.0005)\end{array}$ & $\begin{array}{l}0.0041^{* * *} \\
(0.0003)\end{array}$ \\
\hline gs & $\begin{array}{c}0.8055 \\
(0.5719)\end{array}$ & $\begin{array}{c}0.3220 \\
(0.5425)\end{array}$ & $\begin{array}{c}-1.1293^{* * *} \\
(0.0980)\end{array}$ & $\begin{array}{c}-1.0163^{* * *} \\
(0.0476)\end{array}$ \\
\hline $\exp$ & $\begin{array}{l}1.6085^{* * *} \\
(0.1937)\end{array}$ & $\begin{array}{l}1.7933^{* * * *} \\
(0.1840)\end{array}$ & $\begin{array}{l}0.0658^{* * * *} \\
(0.0215)\end{array}$ & $\begin{array}{l}0.0836^{* * *} \\
(0.0235)\end{array}$ \\
\hline Constant & $\begin{array}{l}9.0311^{* * *} \\
(0.3664)\end{array}$ & $\begin{array}{l}8.09144^{* * *} \\
(0.3638)\end{array}$ & $\begin{array}{l}4.9180^{* * * *} \\
(0.1255)\end{array}$ & $\begin{array}{l}3.8786^{* * *} \\
(0.0966)\end{array}$ \\
\hline Observations & 642 & 642 & 274 & 274 \\
\hline R-squared & 0.3736 & 0.4438 & & \\
\hline $\begin{array}{l}\text { Number of } \\
\text { countries }\end{array}$ & 92 & 92 & 92 & 92 \\
\hline $\begin{array}{l}\text { Sargan test } \\
p \text {-value }\end{array}$ & & & $\begin{array}{c}76.15548 \\
0.3162\end{array}$ & $\begin{array}{c}78.99773 \\
0.4789\end{array}$ \\
\hline $\begin{array}{l}\text { First-order serial } \\
\text { correlation }\end{array}$ & & & -3.9963 & -4.0437 \\
\hline$p$-value & & & 0.0001 & 0.0001 \\
\hline $\begin{array}{l}\text { Second-order } \\
\text { serial correlation }\end{array}$ & & & 1.4445 & 1.0019 \\
\hline$p$-value & & & 0.1486 & 0.3164 \\
\hline
\end{tabular}

Notes: First two columns provide 3-years averaged results of LSDV and last two columns provide results of dynamic two-step system GMM mean to estimate the effect of public debt on GDP growth using ICRG dataset. *** is significant at the $1 \%$ level.

\section{Conclusions}

Previous literature unveiled the fact that public debt adversely affects economic growth after a certain debt threshold level. Furthermore, the importance of governance in stimulating economic growth cannot be ignored. In this context, we examine the intermediating effect of governance on the debt-growth relationship. We use the sample of 106 countries during the period 1996-2015 for our empirical estimation. Previous studies suggest that other 
regressors are considered to be endogenous with GDP growth. To deal with specific effect and endogeneity, we employ the system GMM in our empirical estimation. Moreover, the autocorrelation is tested by using Arellano and Bond correlation test.

Our empirical findings show the nonlinear pattern between debt-growth relationships in the presence of governance. Although, Public debt has negative effect on economic growth but our results show that the interaction term between public debt and economic growth is significant and positive which reveals that after a certain threshold value of governance the adverse effect of public debt turns to be positive. Also, when we use the ICRG dataset as a proxy to measure the governance, the results show the same nonlinear pattern as the results when we used WGIs dataset as a proxy to measure the governance variable. Moreover, for robustness checking of our results, we used the 3 years averaged data for both proxies of governance variable. In both cases, our results show a nonlinear pattern which indicated the consistency of our results in this paper.

These results suggest that poor governance accumulate the public debt means that poor governance magnifies the effect of debt on economic growth. So, we can say good governance is important in order to use the public debt in an efficient and effective way and governance is significant intermediating variable in debt-growth relationship.

In sum, good governance is important to lessen the adverse effect of public debt and make the good use of public debt in development of a country. The developing and underdeveloped countries are suffering badly to higher level of public debt because these countries are facing poor quality of state governance. Poor quality of state governance worsens the adverse effect of debt. So, the governments seeking to reduce the adverse effect of public debt need to improve the quality of governance. Countries facing the adverse effect of public debt need to improve the governance quality to encourage investment; reduce the corruption level, effective use of government spending; improve the competition in market and collection of revenues and taxes, effective regulations to enhance the competitiveness. In this way, country's competitiveness can be improved which results in improving the individuals' life quality.

The impact of public debt on economic growth can be described through different channels. One of them is present sanitary crisis which has increased the debt level at very high values. The policy makers especially in developing countries need to consider this channel for future research. Moreover, considering the non-linearity and threshold regression can also be useful for future research by using the recent data especially during the pandemic time when the debt level is increased in many countries.

Author Contributions: Data curation, Q.A.; formal analysis, Q.A. and M.R.; funding acquisition, L.J.; supervision, L.J.; methodology, M.R.; software, Q.A. and M.R.; review and editing, S.F. All authors have read and agreed to the published version of the manuscript.

Funding: This research was funded by Tianjin " 131 " innovative talent team project: Nankai university 100 young academic leaders (Team) Training support program, Tianjin philosophy and social sciences foundation key projects (2019), China.

Institutional Review Board Statement: Not applicable.

Informed Consent Statement: Not applicable.

Data Availability Statement: The data used in this study is available upon request from the corresponding author.

Acknowledgments: We would like to acknowledge Nankai University, Tianjin, China for administrative and moral support. We are also grateful to the editor and anonymous referees for their valuable comments and suggestions.

Conflicts of Interest: The authors declare no conflict of interest. 


\section{Appendix A}

Table A1. List of Countries.

\begin{tabular}{|c|c|c|c|c|}
\hline Angola & Croatia & Ireland & Namibia & Slovenia \\
\hline Argentina & Cyprus & Italy & Netherlands & South Africa \\
\hline Armenia & Czech Republic & Japan & New Zealand & Spain \\
\hline Australia & Denmark & Jordan & Nicaragua & Sri Lanka \\
\hline Austria & Ecuador & Kazakhstan & Niger & Sweden \\
\hline Bahrain & $\begin{array}{c}\text { Equatorial } \\
\text { Guinea }\end{array}$ & Kenya & Nigeria & Switzerland \\
\hline Barbados & Estonia & Korea, Rep. & Norway & Tajikistan \\
\hline Belgium & Fiji & Kuwait & Panama & Tanzania \\
\hline Benin & Finland & Kyrgyz Republic & Paraguay & Thailand \\
\hline Bolivia & France & Lao PDR & Peru & Togo \\
\hline Botswana & Gabon & Lesotho & Philippines & Tunisia \\
\hline Brazil & Germany & Lithuania & Poland & Turkey \\
\hline Bulgaria & Greece & Luxembourg & Portugal & Ukraine \\
\hline Burkina Faso & Guatemala & Malaysia & Romania & United Kingdom \\
\hline Burundi & Honduras & Malta & Russian Fed. & United States \\
\hline Cameroon & Hong Kong & Mauritania & Rwanda & Uruguay \\
\hline Canada & Hungary & Mauritius & Saudi Arabia & Venezuela, RB \\
\hline Chile & Iceland & Mexico & Senegal & Zimbabwe \\
\hline China & India & Moldova & Serbia & \\
\hline Colombia & Indonesia & Mongolia & Sierra Leone & \\
\hline Costa Rica & $\begin{array}{c}\text { Iran, Islamic } \\
\text { Rep. }\end{array}$ & Morocco & Singapore & \\
\hline Côte d'Ivoire & Iraq & Mozambique & Slovak Republic & \\
\hline
\end{tabular}

Notes: Barbados, Benin, Burundi, Equatorial Guinea, Fiji, Kyrgyz Republic, Lao PDR, Lesotho, Mauritania, Mauritius, Moldova, Panama, Rwanda and Tajikistan are not included in analysis using ICRG dataset because of unavailability of dataset.

Table A2. Correlation matrix 1.

\begin{tabular}{cccccccc}
\hline Variables & GDP & DEBT & TFP & INF & GS & EXP & GOV \\
\hline GDP & 1.0000 & & & & & & \\
DEBT & 0.0252 & 1.0000 & & & & & \\
TFP & 0.6179 & -0.0718 & 1.0000 & & & & \\
INF & -0.1300 & 0.0604 & -0.1020 & 1.0000 & & \\
GS & -0.0237 & 0.0250 & -0.1492 & 0.1003 & 1.0000 & & \\
EXP & 0.5267 & -0.0963 & 0.3799 & -0.0665 & 0.0869 & 1.0000 & \\
GOV & 0.7070 & -0.0541 & 0.7155 & -0.1877 & -0.0423 & 0.4878 & 1.0000 \\
\hline
\end{tabular}

Notes: This correlation matrix is between variables when using WGIs dataset as a proxy for governance variable and missing values are replaced by mean value.

Table A3. Correlation matrix 2.

\begin{tabular}{cccccccc}
\hline Variables & GDP & DEBT & TFP & INF & GS & EXP & ICRG \\
\hline GDP & 1.0000 & & & & & & \\
DEBT & 0.0566 & 1.0000 & & & & & \\
TFP & 0.6384 & -0.0182 & 1.0000 & & & & \\
INF & -0.1269 & 0.0497 & -0.0807 & 1.0000 & & \\
GS & -0.1050 & -0.0088 & -0.1209 & 0.0861 & 1.0000 & & \\
EXP & -0.4813 & -0.0802 & 0.3656 & -0.0565 & -0.0235 & 1.0000 & \\
ICRG & 0.6515 & -0.0603 & 0.6457 & -0.1571 & 0.0592 & 0.4435 & 1.0000
\end{tabular}

Notes: This correlation matrix is between variables when using ICRG dataset as a proxy for governance variable and missing values are replaced by mean value.

\section{References}

1. Reinhart, C.M.; Kenneth, S.R. This Time Is Different; Princeton University Press: Princeton, NJ, USA, 2009.

2. Diamond, P.A. National debt in a neoclassical growth model. Am. Econ. Rev. 1965, 55, 1126-1150. 
3. Saint-Paul, G. Fiscal policy in an endogenous growth model. Q. J. Econ. 1992, 107, 1243-1259. [CrossRef]

4. Barro, R. On the determination of the public debt. J. Polit. Econ. 1979, 87, 940-971. [CrossRef]

5. Dotsey, M. Some unpleasant supply side arithmetic. J. Monet. Econ. 1994, 33, 507-524. [CrossRef]

6. Kim, E.; Ha, Y.; Kim, S. Public Debt, Corruption and Sustainable Economic Growth. Sustainbility 2017, 9, 433. [CrossRef]

7. López, P.J.; Nahón, C. The growth of debt and the debt of growth: Lessons from the case of Argentina. J. Law Soc. 2017, 44, 99-122. [CrossRef]

8. Asiedu, E. Debt relief and institutional reform: A focus on Heavily Indebted Poor Countries. Q. Rev. Econ. Financ. 2003, 43, 614-626. [CrossRef]

9. Dessy, S.E.; Vencatachellum, D. Debt relief and social services expenditure: The African experience, 1989-2003. Afr. Dev. Rev. 2007, 19, 200-216. [CrossRef]

10. Fatás, A.; Mihov, I. Policy volatility, institutions, and economic growth. Rev. Econ. Stat. 2013, 95, 362-376. [CrossRef]

11. Fraj, S.H.; Hamdaoui, M.; Maktouf, S. Governance and economic growth: The role of the exchange rate regime. Int. Econ. 2018, 156, 326-364. [CrossRef]

12. Grindle, M. Good enough governance: Poverty reduction and reform in developing countries. Dev. Policy Rev. 2004, 17, 525-548. [CrossRef]

13. Moshammer, E.; Pierluigi, B.; Masuch, K. Institutions, Public Debt and Growth in Europe. Public Sect. Econ. 2016, 41, 159-205.

14. Tarek, B.A.; Ahmed, Z. Governance and public debt accumulation: Quantitative analysis in MENA countries. Econ. Anal. Policy 2017, 56, 1-13. [CrossRef]

15. Smith, A. The Wealth of Nations [1776]; The Modern Library: New York, NY, USA, 1937; p. 878.

16. Mill, J.S. Principle of Political Economy. 1845. Available online: http://www.gutenberg.org/licens (accessed on 27 March 2020).

17. Ricardo, D.P. On the Principles of Political Economy And Taxation. In The Works and Correspondence of David Ricardo 1; Cambridge University Press: Cambridge, UK, 1951; p. 247.

18. Bal, D.P.; Rath, B.N. Public debt and economic growth in India: A reassessment. Econ. Anal. Policy 2014, 44, 292-300. [CrossRef]

19. Elmendorf, D.W.; Mankiw, N.G. Government debt. Handb. Macroecon. 1999, 1, 1615-1669.

20. Barsky, R.B.; Mankiw, G.N.; Zeldes, S.P. Ricardian Consumers with Keynesian Propensities. Am. Econ. Rev. 1986, 76, 676-691.

21. Leiderman, L.; Razin, A. Testing Ricardian Neutrality with an Intertemporal Stochastic Model. J. Money Credit Bank. 1988, 20, 1-21. [CrossRef]

22. Feldstein, M. The Effects of Fiscal Policies when Incomes Are Uncertain: A Contradiction to Ricardian Equivalence. Am. Econ. Rev. 1988, 78, 14-23.

23. Evans, P. Are Consumers Ricardian? Evidence for the United States. J. Political Econ. 1988, 96, 983-1004. [CrossRef]

24. Evans, P. Is Ricardian Equivalence a Good Approximation? Econ. Inq. 1991, 29, 626-644. [CrossRef]

25. Haug, A.A. Ricardian Equivalence, Rational Expectations, and the Permanent Income Hypothesis. J. Money Credit Bank 1990, 22, 305-326. [CrossRef]

26. Gale, W.G.; Orszag, P.R. The Economic Effects of Long-Term Fiscal Discipline; Urban Institute. 2002. Available online: https: //www.urban.org/research/publication/economic-effects-long-term-fiscal-discipline (accessed on 27 March 2020).

27. Kumar, M.M.S.; Baldacci, M.E. Fiscal Deficits, Public Debt, and Sovereign Bond Yields; International Monetary Fund: Washington, DC, USA, 2010.

28. Corsetti, G.; Kuester, K.; Meier, A.; Müller, G.J. Sovereign risk, fiscal policy, and macroeconomic stability. Econ. J. 2013, 123, F99-F132. [CrossRef]

29. Jacobs, J.; Ogawa, K.; Sterken, E.; Tokutsu, I. Public Debt, Economic Growth and the Real Interest Rate: A Panel VAR Approach to EU and OECD Countries. Appl. Econ. 2019, 52, 1-18. [CrossRef]

30. Sargent, T.J.; Wallace, N. Some unpleasant monetarist arithmetic. Fed. Reserve Bank Minneap. Q. Rev. 1981, 5, 1-17. [CrossRef]

31. Barro, R.J. Inflation and Economic Growth; NBER Working Paper; National Bureau of Economic Research: Cambridge, MA, USA, 1995.

32. Cochrane, J.H. Determinacy and identification with Taylor rules. J. Political Econ. 2011, 119, 565-615. [CrossRef]

33. Aizenman, J.; Kletzer, K.; Pinto, B. Economic Growth with Constraints on Tax Revenues and Public Debt: Implications for Fiscal Policy and Cross-Country Differences; National Bureau of Economic Research: Cambridge, MA, USA, 2007.

34. Woo, J. Why do more polarized countries run more procyclical fiscal policy? Rev. Econ. Stat. 2009, 91, 850-870. [CrossRef]

35. Burnside, A.C.; Eichenbaum, M.S.; Rebelo, S. On the Fiscal Implications of Twin Crises. In Managing Currency Crises in Emerging Markets; University of Chicago Press: Chicago, IL, USA, 2003; pp. 187-224.

36. Khan, M.H. Governance, Economic Growth and Development Since the 1960s; United Nations: New York, NY, USA, 2007.

37. Gani, A. Governance and growth in developing countries. J. Econ. Issues. 2011, 45, 19-40. [CrossRef]

38. Cooray, A. Government expenditure, governance and economic growth. Comp. Econ. Stud. 2009, 51, 401-418. [CrossRef]

39. Kaufmann, D.; Kraay, A.; Mastruzzi, M. Governance Matters IV: Governance Indicators for 1996-2004; The World Bank: Washington, DC, USA, 2005.

40. North, D.C. Institutions, Institutional Change and Economic Performance; Cambridge University Press: Cambridge, UK, 1990.

41. Abdullah, H. Fiscal policy, institutions, and economic growth in Asian countries: Evidence from Pedroni's Cointegration approach. Malays. Manag. J. 2020, 12, 117-135. [CrossRef] 
42. Acemoglu, D.; Johnson, S.; Robinson, J.A. The colonial origins of comparative development: An empirical investigation. Am. Econ. Rev. 2001, 91, 1369-1401. [CrossRef]

43. Adams, S.; Mengistu, B. Privatization, governance and economic development in developing countries. J. Dev. Soc. 2008, 24, 415-438. [CrossRef]

44. Ndulu, B.J.; O'Connell, S.A. Governance and growth in sub-Saharan Africa. J. Econ. Perspect. 1999, 13, 41-66. [CrossRef]

45. Globerman, S.; Shapiro, D. Global foreign direct investment flows: The role of governance infrastructure. World Dev. 2002, 30, 1899-1919. [CrossRef]

46. Jalilian, H.; Kirkpatrick, C.; Parker, D. The impact of regulation on economic growth in developing countries: A cross-country analysis. World Dev. 2007, 35, 87-103. [CrossRef]

47. Kaufmann, D.; Kraay, A. Growth Without Governance; The World Bank: Washington, DC, USA, 2002.

48. Méon, P.-G.; Sekkat, K. Does corruption grease or sand the wheels of growth? Public Choice 2005, 122, 69-97. [CrossRef]

49. Schneider, F.; Buehn, A.; Montenegro, C.E. Shadow Economies All Over the World: New Estimates for 162 Countries from 1999 to 2007; World Bank Policy Research Working Paper; World Bank: Washington, DC, USA, 2010.

50. Cukierman, A.; Meltzer, A.H. A political theory of government debt and deficits in a neo-ricardian framework. Amer. Econ. Rev. $1989,79,713-732$.

51. Debortoli, D.; Nunes, R. Political disagreement, lack of commitment and the level of debt. Int. Financ. Discuss. Pap. 2008, 938. [CrossRef]

52. Lambsdorff, J.G. How corruption affects productivity. Kyklos 2003, 56, 457-474. [CrossRef]

53. Woo, J. Economic, political, and institutional determinants of public deficits. Political Econ. Fisc. Policy Public Deficits Volatility Growth 2006, 570, 77-116.

54. Persson, T.; Svensson, L.E. Why a stubborn conservative would run a deficit: Policy with time-inconsistent preferences. Q. J. Econ. 1989, 104, 325-345. [CrossRef]

55. Alesina, A.; Tabellini, G. A positive theory of fiscal deficits and government debt. Rev. Econ. Stud. 1990, 57, 403-414. [CrossRef]

56. Cooray, A.; Dzhumashev, R.; Schneider, F. How does corruption affect public debt? An empirical analysis. World Dev. 2017, 90, 115-127. [CrossRef]

57. González-Fernández, M.; González-Velasco, C. Shadow economy, corruption and public debt in Spain. J. Policy Modeling 2014, 36, 1101-1117. [CrossRef]

58. Benfratello, L.; Del Monte, A.; Pennacchio, L. Corruption and public debt: A cross-country analysis. Appl. Econ. Lett. 2018, 25, 340-344. [CrossRef]

59. Grechyna, D. Public Corruption and Public Debt: Some Empirical Evidence. 2012. Available online: https://papers.ssrn.com/ sol3 / papers.cfm?abstract_id=2052974 (accessed on 27 March 2020).

60. Mauro, P. Corruption and the composition of government expenditure. J. Public Econ. 1998, 69, 263-279. [CrossRef]

61. De la Croix, D.; Delavallade, C. Democracy, rule of law, corruption incentives, and growth. J. Public Econ. Theory 2011, 13, 155-187. [CrossRef]

62. Wei, S.-J.; Zeckhauser, R. Dark deals and dampened destinies: Corruption and economic performance. Jpn. World Econ. 1999, 11, 443-454.

63. Kaufmann, D. Can corruption adversely affect public finances in industrialized countries. Brook. Inst. April 2010, 19. Available online: https: / / www.brookings.edu/opinions / can-corruption-adversely-affect-public-finances-in-industrialized-countries / (accessed on 27 March 2020).

64. Schultz, K.A.; Weingast, B.R. The democratic advantage: Institutional foundations of financial power in international competition. Int. Organ. 2003, 57, 3-42. [CrossRef]

65. Neumayer, E. Is good governance rewarded? A cross-national analysis of debt forgiveness. World Dev. 2002, 30, 913-930. [CrossRef]

66. Haber, S.H.; North, D.C.; Weingast, B.R. Political Institutions and Financial Development; Stanford University Press: Palo Alto, CA, USA, 2008.

67. Roe, M.J.; Siegel, J.I. Political instability: Effects on financial development, roots in the severity of economic inequality. J. Comp. Econ. 2011, 39, 279-309. [CrossRef]

68. Rajan, R.G.; Zingales, L. The great reversals: The politics of financial development in the twentieth century. J. Financ. Econ. 2003, 69, 5-50. [CrossRef]

69. Mehlum, H.; Moene, K.; Torvik, R. Cursed by resources or institutions? World Econ. 2006, 29, 1117-1131. [CrossRef]

70. Parker, D. Regulation of privatised public utilities in the UK: Performance and governance. Int. J. Public Sect. Manag. 1999, 12, 213-236. [CrossRef]

71. Bosco, B. Old and new factors affecting corruption in Europe: Evidence from panel data. Econ. Anal. Policy 2016, 51, 66-85. [CrossRef]

72. Sala-i-Martin, X.; Doppelhofer, G.; Miller, R.I. Determinants of long-term growth: A Bayesian averaging of classical estimates (BACE) approach. Am. Econ. Rev. 2004, 813-835. [CrossRef]

73. Mankiw, N.G.; Romer, D.; Weil, D.N. A contribution to the empirics of economic growth. Q. J. Econ. 1992, 107, 407-437. [CrossRef]

74. Pattillo, C.A.; Poirson, H.; Ricci, L.A. External Debt and Growth; International Monetary Fund: Washington, DC, USA, 2002. 
75. Cunningham, R.T. The effects of debt burden on economic growth in heavily indebted developing nations. J. Econ. Dev. 1993, 18, 115-126.

76. Olson, M.; Sarna, N.; Swamy, A.V. Governance and growth: A simple hypothesis explaining cross-country differences in productivity growth. Public Choice 2000, 102, 341-364. [CrossRef]

77. Kaufmann, D.; Kraay, A. Governance and Growth: Causality which Way? Evidence for the World, In Brief; World Bank: Washington, DC, USA, 2003.

78. Seldadyo, H.; Nugroho, E.P.; De Haan, J. Governance and growth revisited. Kyklos 2007, 60, 279-290. [CrossRef]

79. Huynh, K.P.; Jacho-Chávez, D.T. Growth and governance: A nonparametric analysis. J. Comp. Econ. 2009, 37, 121-143. [CrossRef]

80. Woo, J.; Kumar, M.S. Public Debt and Growth. Economica 2015, 82, 705-739. [CrossRef]

81. Checherita-Westphal, C.D.; Rother, P. The Impact of High and Growing Government Debt on Economic Growth: An Empirical Investigation for the Euro Area. Eur. Econ. Rev. 2012, 56, 1392-1405. [CrossRef]

82. Reinhart, C.M.; Rogoff, K.S. Growth in a Time of Debt. Am. Econ. Rev. 2010, 100, 573-578. [CrossRef]

83. Hausman, J.A. Specification tests in econometrics. Econom. J. Econom. Soc. 1978, 1251-1271. [CrossRef]

84. Arellano, M.; Bond, S. Some tests of specification for panel data: Monte Carlo evidence and an application to employment equations. Rev. Econ. Stud. 1991, 58, 277-297. [CrossRef]

85. Blundell, R.; Bond, S. Initial conditions and moment restrictions in dynamic panel data models. J. Econom. 1998, 87, 115-143. [CrossRef]

86. Sargan, J.D. The estimation of economic relationships using instrumental variables. Econom. J. Econom. Soc. 1958, 393-415. [CrossRef]

87. Kaufman, D.; Kraay, A.; Mastruzzi, M. The Worldwide Governance Indicators: Methodology and Analytical Issues; World Bank Policy Research Working Paper (5430); World Bank: Washington, DC, USA, 2010.

88. Setayesh, M.H.; Daryaei, A.A. Good governance, innovation, economic growth and the stock market turnover rate. J. Int. Trade Econ. Dev. 2017, 26, 829-850. [CrossRef]

89. Mehanna, R.-A.; Yazbeck, Y.; Sarieddine, L. Governance and Economic Development in MENA Countries: Does Oil Affect the Presence of a Virtuous Circle? J. Transnatl. Manag. 2010, 15, 117-150. [CrossRef]

90. Morrissey, O.; Udomkerdmongkol, M. Governance, private investment and foreign direct investment in developing countries. World Dev. 2012, 40, 437-445. [CrossRef]

91. Kolstad, I.; Villanger, E. Determinants of foreign direct investment in services. Eur. J. Political Econ. 2008, 24, 518-533. [CrossRef]

92. Afonso, A.; Jalles, J.T. Growth and productivity: The role of government debt. Int. Rev. Econ. Financ. 2013, 25, 384-407. [CrossRef]

93. Eberhardt, M.; Presbitero, A.F. Public debt and growth: Heterogeneity and non-linearity. J. Int. Econ. 2015, 97, 45-58. [CrossRef]

94. Panizza, U.; Presbitero, A.F. Public debt and economic growth: Is there a causal effect? J. Macroecon. 2014, 41, 21-41. [CrossRef]

95. Moore, M. Political Underdevelopment: What causes 'bad governance'. Public Manag. Rev. 2001, 3, 385-418. [CrossRef]

96. Habtamu, F.N. Roles of Governance in explaining economic growth in sub-Saharan Africa. Afr. Policy J. $2008,4,1-21$.

97. Bellakhal, R.; Kheder, S.B.; Haffoudhi, H. Governance and renewable energy investment in MENA countries: How does trade matter? Energy Econ. 2019, 84, 104541. [CrossRef] 